\title{
GENETIC VARIABILITY AND RELATIONSHIPS AMONG SUGARCANE VARIETIES BASED ON CHECKED TRAP MARKERS OF STRESS TOLERANCE CANDIDATE GENES AND SOME AGRONOMIC TRAITS \\ Amein, K. A. and H. M. El-Aref \\ Dept. of Genetics, Faculty of Agriculture, Assiut University, Assiut, Egypt.
}

\begin{abstract}
The advantages of target region amplification polymorphism (TRAP) for identification of polymorphisms in coding regions obtained from EST library were used to determine the genetic variability and relationships among 10 sugarcane varieties. TRAP fixed primers based on CDPK and Aqua candidate genes involved in stress tolerance were paired with three arbitrary primers to produce 6 primer combinations. $A$ total of 60 DNA fragments with an average of 10 bands per primer combination were generated from 10 sugarcane genotypes. The percentage of polymorphism was $55.17 \%$ and $54.84 \%$ in CDPK and Aqua loci, respectively. The largest number of amplified fragments was obtained with the Aqua + arbit.3 primer combination (14 bands), and the lowest ( 6 bands) with the Aqua + arbit.1. The highest number of TRAP markers was amplified from EI 24-3 OR 2 and G95-19, while the least number of bands was obtained from G.98-28, N.CO.310 and EH 16-9. The lowest similarity were obtained between N.CO.310 and G95-21 reflecting high diversity among them and suggested that crosses between these two genotypes would probably result in the highest variability for stress tolerance. The dendrogram classified the genotypes based on their pedigree in which varieties that have common parent were grouped together based on the polymorphism in CDPK and Aqua loci. The results indicated that the TRAP markers can provide a powerful technique for genetic diversity in sugarcane.

The performance of the sugarcane varieties in stalk traits (height, diameter and number) and cane yield were studied in two seasons. Maximum genetic advance along with high heritability was observed for stalk height, reflecting the preponderance of additive gene action in determining such character, so reliable selection could be made for this trait on the basis of phenotypic expression. The other traits displayed high amount of heritability associated with low genetic advance indicating that nonadditive gene action governing these traits, which could be improved through hybridization and hybrid vigor.
\end{abstract}

Keywords:sugarcane, target region amplification polymorphism, TRAP, CDPK and Aqua candidate genes.

\section{INTRODUCTION}

Sugarcane (SaccharumofficinirumL.) varieties in commercial cultivation are complex heterozygous polyploid. The information on the nature and the magnitude of variability present in the genetic material is of prime importance for a breeder to initiate any effective selection program (Anshumanet.al., 2002). Traditional methods which combined agronomic and morphological characteristics have been useful in identifying and describing differences between members of the Saccharum complex (Skinneret.al., 1987). 
However, members of the Saccharum complex are predominantly out crossing and are maintained by vegetative propagation. As such, they are highly heterozygous and display enormous plasticity in the phenotypic expression of traits. Although morphological traits can be used to identify and classify clones, most of the traits are influenced by the environment under which the clones are grown or selected.

Molecular markers now make it possible to assess genetic diversity at the DNA level. Gene targeted molecular markers may be more promising and meaningful than random DNA markers in terms of characterizing genetic diversity. Whereas random DNA markers are derived from polymorphic sites genome wide, gene targeted markers are derived from polymorphisms within genes and thus reflect functional polymorphism (Andersen and Lubberstedt, 2003).

The Target Region Amplification Polymorphism (TRAP) introduced by $\mathrm{Hu}$ and Vick (2003) have been designed that take advantage of the increasingly growing open online access to EST sequences obtained from diverse cDNA libraries. TRAP is a novel polymerase chain reaction (PCR)based marker system that takes advantage of the available EST database sequence information to generate polymorphic markers targeting candidate genes. Essentially it derives an 18-mer primer from the EST sequence and pairs it with an arbitrary primer that targets the intronic and/or exonic region (AT- or GC- rich core) (Li and Quiros, 2001). Since TRAP is based on PCR technology using anchored and arbitrary primers to amplify coding regions in the genome, the resulting polymorphism should be reflective of diversity within functional genes.

Promising observations from the evaluation of aquaporins among stress resistance or sensitive plants, such as drought susceptible and drought tolerant wheat cultivars, (Morillon and Lassalles, 2002), sugarcane genotypes (Creste et al., 2010), other crop cultivars (Lian et al., 2004), or stressed EST libraries (Houde et al., 2006), clearly indicated that aquaporins would be important for water uptake, transport and identification or development of any stress tolerant genotypes of crop species. While, Calcium-dependent protein kinases (CDPKs) sense the calcium concentration changes in plant cells and play important roles in signaling pathways for disease resistance and various stress responses ( $\mathrm{Li}$ et al., 2008). In the present study, TRAP markers were used to assess the genetic variability among sugarcane genotypes based on CDPK and Aqua candidate genes involved in stress tolerance. In addition, the agronomic performance of the tested varieties was evaluated in two seasons.

\section{MATERIALS AND METHODS}

Plant materials: Ten sugarcane (Saccharum officinarum L.) varieties were kindly obtained from the research station of Sugar and Integrated Industries Company. These entries included the present commercial cultivars G.T.54C9 and previous one NCO310 while the other genotypes were elite varieties could be released instead of the commercial varieties (Table 1). 
Table (1): The studied sugarcane genotypes and their parents.

\begin{tabular}{|l|c|c|}
\hline \multirow{2}{*}{ Genotypes } & \multicolumn{2}{|c|}{ Parents } \\
\cline { 2 - 3 } & open & C \\
\hline G.98-28 & Cp.76-1306 & Q.76-1053 \\
\hline G99-165 & Sp.79-2278 & Sp. 80-1043 \\
\hline G95-19 & Sp.79-2278 & Sp. 80-1043 \\
\hline G84-47 & open & NCo.310 \\
\hline N.CO.310 & CO321 & CO421 \\
\hline G.T.54C-9 & F37-925 (Pas 38X F83) & NCo.310 \\
\hline El 24-3 OR 2 & BU459 & PR1117 \\
\hline EH 16-9 & LCP81-30 & CP81-325 \\
\hline PH8013 & Phil.64-2227 & CAC71-312 \\
\hline
\end{tabular}

Isolation of Sugarcane DNA: The total DNA isolation from fresh sugarcane leaf roll was carried out according to Dellaporta modified protocol (Dellaporta et al., 1983). Concentrations of extracted DNA were estimated by known concentration of Lambada DNA in $1 \%(W / V)$ agarose gel.

PCR primers design: Target region amplification polymorphism (TRAP) is a simple 2-primers (fixed and arbitrary primers) polymerase chain reaction (PCR) technique. The forward (fixed) primer was designed from genes or EST sequences and the accompanied reverse (arbitrary) primer was designed to target either the exonic (GC rich) or intronic (AT rich) region of the genome ( $\mathrm{Li}$ and Quiros, 2001 and $\mathrm{Hu}$ and Vick, 2003). Two genes included that are Calcium-dependent protein kinases (CDPKs) and Aquaporin (Aqua) involved in stress tolerance in combination with three arbitrary primers according to Li and Quiros (2001) were used in this study as given in Table (2).

Table(2):Sequence data of two fixed primers and three arbitrary primers used to estimate the genetic variability in ten sugarcane varieties.

\begin{tabular}{|c|c|c|c|c|}
\hline Primer & Sequence $\left(5^{\prime} \rightarrow 3^{\prime}\right)$ & $\begin{array}{c}\text { GenBank } \\
\text { ID }\end{array}$ & Sequence ID & References \\
\hline \multicolumn{5}{|l|}{$\begin{array}{l}\text { Fixed } \\
\text { primer }\end{array}$} \\
\hline CDPK & ACAGAACCACCAAAGGAG & CF572977 & $\begin{array}{c}\text { Stress } \\
\text { tolerance }\end{array}$ & $\begin{array}{c}\text { Vettore et al. } \\
(2001)\end{array}$ \\
\hline Aqua & ATCTCCGGCGGCCACAT & CA086489 & $\begin{array}{c}\text { Water } \\
\text { channel }\end{array}$ & $\begin{array}{c}\text { Vettore et al. } \\
(2001)\end{array}$ \\
\hline \multicolumn{5}{|c|}{$\begin{array}{l}\text { Arbitrary } \\
\text { primer }\end{array}$} \\
\hline Arbit.1 & GACTGCGTACGAATTAAT & & & $\begin{array}{c}\text { Li and Quiros } \\
(2001)\end{array}$ \\
\hline Arbit.2 & GACTGCGTACGAATTGAC & & & $\begin{array}{c}\text { Li and Quiros } \\
(2001)\end{array}$ \\
\hline Arbit.3 & GACTGCGTACGAATTTGA & & & $\begin{array}{c}\text { Li and Quiros } \\
(2001)\end{array}$ \\
\hline
\end{tabular}


The primers were designed on the basis of the web-based PCR primer design software Primer 3 (http: // frodo. wi. mit. Edu / cgibin/primer3/primer3_www.cgi) using the following parameters: a primer optimal $\mathrm{Tm}$, maximum $\mathrm{Tm}$, and minimum $\mathrm{Tm}$ of 53,55 and $50^{\circ} \mathrm{C}$, respectively, and a GC content between 40 and $60 \%$.

PCR Protocol: TRAP reactions were performed based on the protocol of $\mathrm{Hu}$ and Vick (2003). Fixed primers were combined with each of three arbitrary primers for a total of 6 primer combinations. Each reaction was carried out in a total volume of $20 / \mu \mathrm{L}$ containing $2 / \mu \mathrm{L}$ of $10 x$ PCR buffer, $0.5 / \mu \mathrm{L}$ of $100 \mathrm{mM}$ $\mathrm{MgCl}_{2}, 1.0 / \mu \mathrm{L}$ each of $10 / \mathrm{pmol}$ fixed and arbitrary primers, $1 . / \mu \mathrm{L}$ of $10 \mathrm{mM}$ dNTPs (Promega, Madison, WI USA), $0.35 / \mu \mathrm{L}$ of $5 \mathrm{U}$ Taq polymerase (Promega, Madison, WI USA) and $1.0 / \mu \mathrm{L}$ of $50 \mathrm{ng}$ genomic DNA and in the final added $13.15 / \mu \mathrm{L}$ of nuclease free water to complete the total reaction . The conditions for PCR were as follows: an initial denaturing step was performed at $94^{\circ} \mathrm{C}$ for $4 \mathrm{~min}$ followed by 5 cycles at $94^{\circ} \mathrm{C}$ for $45 \mathrm{~s}, 35^{\circ} \mathrm{C}$ for $45 \mathrm{~s}$ and $72^{\circ} \mathrm{C}$ for $1 \mathrm{~min}$, followed by 35 cycles at $94^{\circ} \mathrm{C}$ for $45 \mathrm{~s}, 53^{\circ} \mathrm{C}$ for $45 \mathrm{~s}$ and $72^{\circ} \mathrm{C}$ for $1 \mathrm{~min}$ with a final extension step at $72^{\circ} \mathrm{C}$ for $7 \mathrm{~min}$. All the PCR reactions were performed on a My Gene ${ }^{\mathrm{TM}}$ series peltire thermal cycler Model MG 96G (long Gene®).

Electrophoresis: After PCR, the amplified products were run on $4 \%$ agarose gel in 0.5X TBE buffer. Ethidium bromide was added before pouring the gel in the submarine electrophoresis unit, to give a final concentration of $0.5 \mu \mathrm{g} / \mathrm{ml}$ of Eth $\mathrm{Br}$. One Kbp DNA ladder was used as a standard. The electrophoresis run was performed at $80 \mathrm{~V}$ in DNA electrophoresis unit (Biometra) for120 to 150 mins. Photograph was taken under UV light using gel documentation system.

Data analysis: Data were scored as (1) presence of band and (0) absence of band from TRAP of amplification profile. The pairwise comparisons between the tested genotypes were used to calculate the coefficient of genetic similarity (GS) matrix according to Nei and Li (1979) using the software package MVSP (Multi-Variate Statistical Package). Cluster analysis was presented as the dendrogram based on similarity estimates using the unweighted pair-group method with arithmetic average (UPGMA).

Field Experiment: The investigation was carried out during two successive seasons (March, 2011/2012, and March, 2012/2013). The experiments were laid out according to Randomized Complete Block Design (RCBD) having four replicates. The plot size was $54 \mathrm{~m}^{2}$, consisted of twelve rows, each of seven meters in length spaced at $70 \mathrm{~cm}$ apart. Ten plants were cultivated in each raw. The agronomic practices were carried out as recommended in the region. The crop was harvested manually at its physiological maturity at 11 months age for the three seasons.

Data recorded: At harvest,stalk height $(\mathrm{cm})$, stalk diameter $(\mathrm{cm})$, stalk number $/ \mathrm{m}^{2}$ and cane yield were determined.

Statistical analysis: The combined analysis of variance over the two seasons was carried out and the portioning of the mean squares in addition to heritability and genetic advance were calculated as described by Kang et al (1983) and Fehr (1987). 


\section{RESULTS AND DISCUSSION}

\section{I- TRAP markers based on CDPK and Aqua candidate genes:}

Genetic variability among 10 sugarcane varieties were studied using TRAP analysis based on the polymorphism in two candidate genes involved in stress tolerance namely; Aquaporin (Aqua) and Calcium-dependent protein kinase (CDPK). TRAP analysis of 6 primer combinations resulted from two fixed forward primers of Aqua and CDPK loci and three arbitrary reverse primers gave a total of 60 DNA bands, with an average of 10 bands per primer combination (Table 3 and Figs. 1\&2). The number of amplified bands was 29 and 31 while the percentage of polymorphic bands was $55.17 \%$ and $54.84 \%$ in CDPK and Aqua loci with $55.00 \%$ overall polymorphism, respectively. The largest number of amplified fragments was observed with the Aqua + arbit.3 primer combination (14 bands), and the lowest ( 6 bands) with the Aqua + arbit.1. Meanwhile, CDPK+arbit.3 generated the highest percentage of polymorphic bands (84.62\%) and CDPK+arbit.1 displayed the lowest polymorphism (22.22\%). D'Hont et al., (1996) and Ming et al., (2001) reported that the occurrence of a highly polymorphic band profile in sugarcane can be attributed to the fact that sugarcane is a highly selfincompatible, cross-pollinating, complex polyploid grass species with homologous and homologous chromosomes.

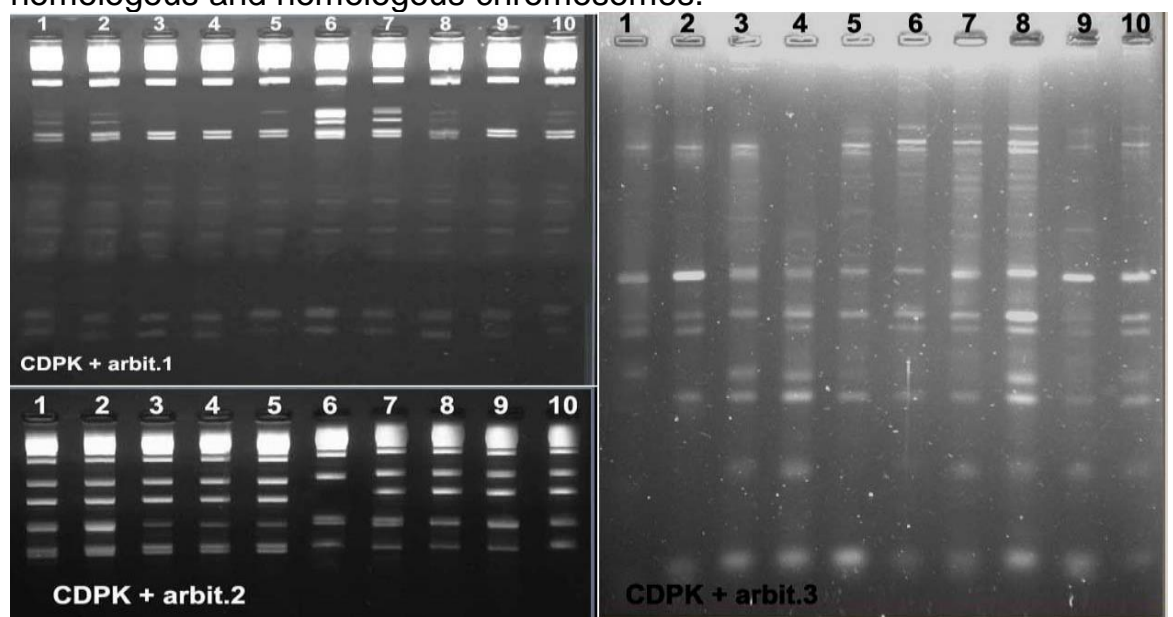

Fig.(1). TRAP profile of sugarcane varieties using CDPK locus; (1) G.9828, (2) G99-165, (3) G95-19, (4) G95-21, (5) G84 - 47, (6) N.CO.310, (7) G.T.54C-9, (8) El 24-3 OR2, (9 EH 16-9 and (10) PH8013. 


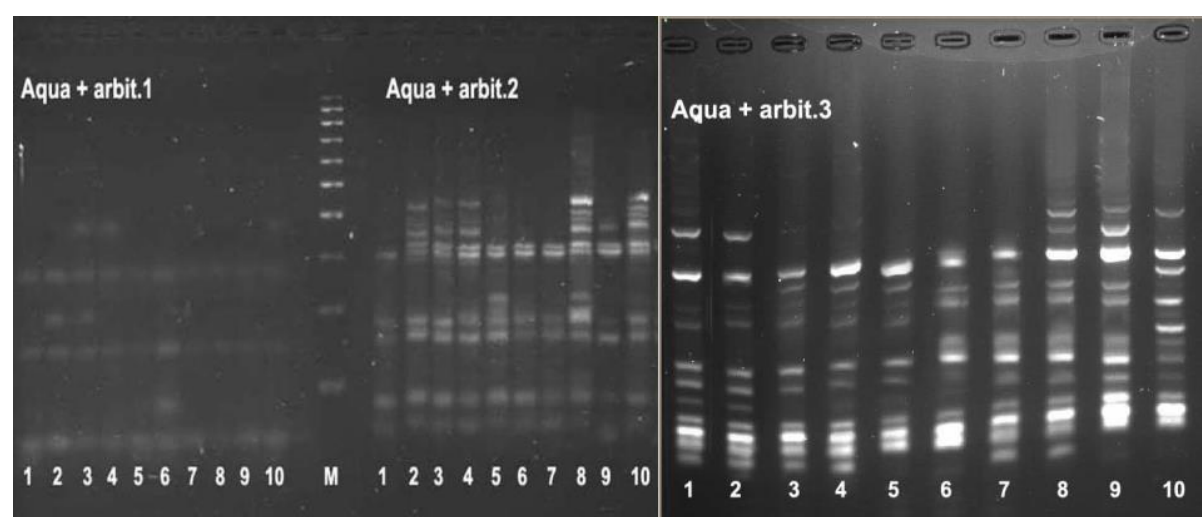

Fig.(2). TRAP profile of sugarcane varieties using Aqua locus; (1) G.9828, (2) G99-165, (3) G95-19, (4) G95-21, (5) G84 - 47, (6) N.CO.310, (7) G.T.54C-9, (8) El 24-3 OR2, (9 EH 16-9 and (10) PH8013.

Table (3): Number of amplified DNA-fragments, polymorphic bands and $\%$ of polymorphism, in ten sugarcane varieties investigated with TRAP markers by six primer combinations of CDPK and Aqua loci.

\begin{tabular}{|c|c|c|c|c|c|c|c|c|c|c|c|c|c|c|}
\hline \multirow[b]{2}{*}{$\begin{array}{l}\text { Fixed } \\
\text { primer }\end{array}$} & \multirow[b]{2}{*}{$\begin{array}{l}\text { Arbitrary } \\
\text { primer }\end{array}$} & \multicolumn{10}{|c|}{ No. of amplified bands } & \multirow{2}{*}{ 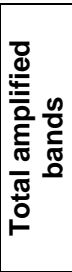 } & \multirow{2}{*}{ 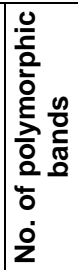 } & \multirow{2}{*}{ 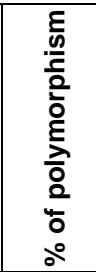 } \\
\hline & & 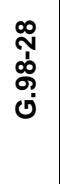 & 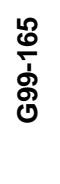 & $\begin{array}{l}\frac{O}{\dot{1}} \\
\text { : } \\
\text { Oे }\end{array}$ & $\begin{array}{l}\bar{N} \\
\text { Н⿱ } \\
\text { Oे }\end{array}$ & $\begin{array}{l}\text { f } \\
1 \\
\text { J } \\
\text { O }\end{array}$ & 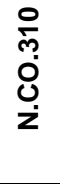 & 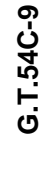 & 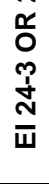 & 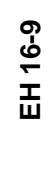 & $\begin{array}{l}\stackrel{m}{\delta} \\
\frac{\infty}{T} \\
\frac{0}{\alpha}\end{array}$ & & & \\
\hline \multirow{3}{*}{ CDPK } & arbit-1 & 9 & 9 & 7 & 7 & 8 & 9 & 9 & 9 & 7 & 9 & 9 & 2 & 22.22 \\
\hline & arbit-2 & 6 & 6 & 6 & 6 & 6 & 6 & 6 & 5 & 6 & 5 & 7 & 3 & 42.86 \\
\hline & arbit-3 & 5 & 6 & 10 & 7 & 9 & 9 & 11 & 12 & 8 & 9 & 13 & 11 & 84.62 \\
\hline \multicolumn{2}{|l|}{ Total } & 20 & 21 & 23 & 20 & 23 & 24 & 26 & 26 & 21 & 23 & 29 & 16 & 55.17 \\
\hline \multirow{3}{*}{ Aqua } & arbit-1 & 3 & 4 & 5 & 4 & 3 & 4 & 3 & 3 & 3 & 4 & 6 & 3 & 50.00 \\
\hline & arbit-2 & 5 & 10 & 10 & 10 & 7 & 6 & 6 & 11 & 7 & 10 & 11 & 6 & 54.55 \\
\hline & arbit-3 & 11 & 11 & 10 & 10 & 10 & 8 & 10 & 12 & 11 & 9 & 14 & 8 & 57.14 \\
\hline \multicolumn{2}{|l|}{ Total } & 19 & 25 & 25 & 24 & 20 & 18 & 19 & 26 & 21 & 23 & 31 & 17 & 54.84 \\
\hline \multicolumn{2}{|c|}{ Grand TOTAL } & 39 & 46 & 48 & 44 & 43 & 42 & 45 & 52 & 42 & 46 & 60 & 33 & 55.00 \\
\hline
\end{tabular}

High variability in TRAP markers of CDPK and Aqua loci was found between the tested sugarcane varieties. Over the tested loci (Table 3), the highest number of TRAP markers was amplified from EI 24-3 OR 2 (52 bands) followed by G95-19 (48 bands). While, the least number of bands was obtained from G.98-28 (39 bands) followed by N.CO.310 and EH 16-9 (42 bands, each). The other genotypes G84 - 47, G95-21, G.T.54C-9, G99165 and PH8013 displayed 43, 44, 45, 46 and 46 DNA bands of CDPK and Aqua loci, respectively. 
Using four primer combinations, Arro (2005) amplified a total of 378 CDPK band from 60 sugarcane genotypes and 336 of them were polymorphic. Alwala et al. (2006) amplified 108 CDPK bands from 30 sugarcane germplams by three primer combinations and found high percentages of polymorphism ranged from 82.75 to $100 \%$.Creste et al. (2010) amplified 60 Aqua bands from 60 sugarcane genotypes by three primer combinations. They found that the largest number of polymorphic fragments was obtained with the Aqua/Arb2 (24 fragments) primer combination. Khan et al. (2011) identified elite sugarcane clones by TRAP analysis and detected 3-4 bands in the profile of CDPK depending on the genotype. They detected specific DNA segment at 517 bp which can be used for the identification of sugarcane clones through TRAP marker. Recently, Fawaz (2014) detected high polymorphism in Aqua locus (37/55 bands, $67.27 \%$ ) when 12 sugarcane varieties were analyzed by three TRAP primers.

TRAP markers are derived from candidate genes representing functional markers that may be directly involved with a phenotypic trait variation. In the present study, specific regions of the sugarcane genome related to stress tolerance (CDPK and Aqua loci), rather than the entire genome, were sampled to evaluate the genetic variability of the important sugarcane genotypes. The results in Table (4) revealed that the lowest similarity $(\mathrm{Si}=0.729 \%)$ was obtained between the genotypes N.CO.310 and G95-21. These results illustrating that crosses between these two genotypes would probably result in the highest variability for stress tolerance. Becelaere et al. (2005) reported that crosses between unrelated genotypes will maximize the number of segregating alleles, resulting in a large genetic variance in the progeny, thereby increasing the opportunity for selecting rare genotypes that may be superior. It has been suggested that genetic diversity estimation for planning crossing purposes should be done based on candidate genes for specific traits (Alwala et al. 2006). The results also revealed that the highest genetic similarity was observed between N.CO.310 and G.T.54C-9 ( $\mathrm{Si}=0.930$ ) followed by G95-21 and $\mathrm{G} 95-19$ ( $\mathrm{Si}=0.913)$, and between EI 24-3 OR2 and G.T.54C-9 ( $\mathrm{Si=0.907).}$

Table (4): Genetic similarity values calculated from the TRAP markers amplified from ten sugarcane varieties by six primer combinations of CDPK and Aqua loci.

\begin{tabular}{|c|c|c|c|c|c|c|c|c|c|c|}
\hline Genotypes & 1 & 2 & 3 & 4 & 5 & 6 & 7 & 8 & 9 & 10 \\
\hline 1- G.98-28 & -- & & & & & & & & & \\
\hline 2- G99-165 & 0.894 & -- & & & & & & & & \\
\hline 3- G95-19 & 0.782 & 0.872 & -- & & & & & & & \\
\hline 4- G95-21 & 0.819 & 0.867 & 0.913 & -- & & & & & & \\
\hline 5- G84-47 & 0.805 & 0.809 & 0.857 & 0.782 & -- & & & & & \\
\hline 6- N.CO.310 & 0.800 & 0.805 & 0.764 & 0.729 & 0.881 & -- & & & & \\
\hline 7- G.T.54C-9 & 0.833 & 0.835 & 0.817 & 0.809 & 0.886 & 0.930 & -- & & & \\
\hline 8- El 24-3 OR2 & 0.813 & 0.878 & 0.860 & 0.854 & 0.842 & 0.839 & \begin{tabular}{|l|}
0.907 \\
\end{tabular} & -- & & \\
\hline 9- EH 16-9 & 0.825 & 0.828 & 0.787 & 0.847 & 0.833 & 0.829 & 0.884 & 0.882 & -- & \\
\hline \begin{tabular}{|l|}
$10-\mathrm{PH} 8013$ \\
\end{tabular} & 0.800 & 0.870 & 0.851 & 0.867 & 0.809 & 0.805 & 0.835 & 0.898 & 0.851 & -- \\
\hline
\end{tabular}


The grouping of sugarcane varieties based on the polymorphism found in CDPK and Aqua loci analyzed by TRAP are presented in Fig. (3). The dendrogram tree showed that the 10 sugarcane varieties were clustered together in two main groups of clusters within a branched-off 0.820 genetic similarity (GS). The first group contained three genotypes that have NCO310 common parent, in which G.T.54C9 and NCO310 were clustered together firstly at 0.930 GS and then with G84-47 at 0.884 GS. The second group contains three sub-clusters. The first one contained EI 24-3 OR 2 and PH8013 at 0.868 GS and clustered with EH 16-9 within 0.866 GS. The second sub-cluster contains $G$ 95-19 and G 95-21 which have the common parent and showed the highest GS (0.913). Both G.98-28 and G.99-165 were grouped in the $3^{\text {rd }}$ sub-cluster at $0.894 \mathrm{GS}$. The above results revealed that some varieties that have common parent were grouped together (varieties G.T.54C9, NCO310 and G84-47 as well as G.98-28 and G.99-165) based on the polymorphism in CDPK and Aqua loci. Similar results were also obtained by Arro (2005) and Fawaz (2014).

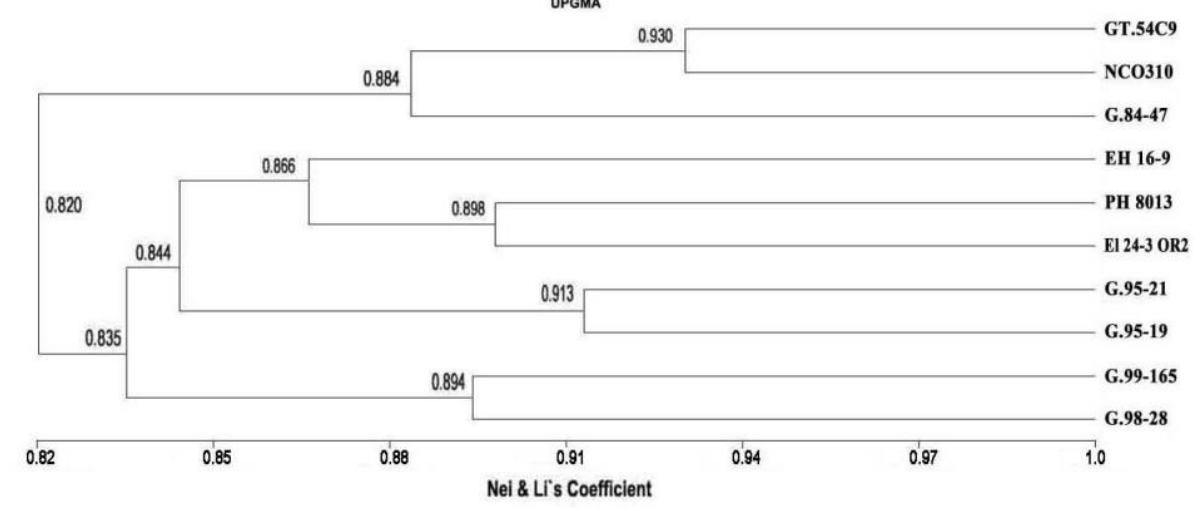

Fig.(3):Dendrogram demonstrating the relationships among 10 sugarcane varieties based on data recorded from polymorphism of TRAP markers of CDPK and Aqua genes.

\section{II-Genetic analysis and expected response to selection for some agronomic traits.}

The information on the nature and the magnitude of variability present in the genetic material is of prime importance for the breeder to initiate any effective selection program (Tyagi and Singh, 1998). In the present investigation, 10 varieties of sugarcane were studied in two seasons to assess their genetic potential for stalk traits (height, diameter and number) and cane yield (Table 5). Average over seasons, the tallest stalks were found in G.T 54-9 $(272.9 \mathrm{~cm})$ and G.84-47 $(271.3 \mathrm{~cm})$, while EH 16-9 $(194.4 \mathrm{~cm})$ displayed the shortest stalks (Table 5 ). The genotype G95-19 followed by G.T 54-9 revealed the highest values of stalk diameter $(3.10,2.95 \mathrm{~cm}$, respectively). While, NCO310 revealed the lowest stalk diameter $(2.55 \mathrm{~cm})$. The highest number of stalks was produced by G.84-47 (13.35 stalks) followed by G.T 54-9 (13.20 stalks), while G99-165 produced the lowest 
number (8.35 stalks). The four genotypes G.T 54-9, G95-21, G95-19 and G.98-28 displayed the highest cane yield ranged from 53.5 to 50 ton/fed. While, EH 16-9 and G99-165 revealed the lowest yield (32.4 and 39.5 tons, respectively). The other varieties NCO310, El 24-3 OR 2, PH 8013 and G.8447 produced $42.7,45.8,47.5$ and 49.1 tons/fed., respectively. Similar results were also obtained by Chaudhary, 2001 and Ahmed and Obeid, 2012.

Table 5.The mean values of stalk height, diameter and number in addition to cane yield of 10 sugarcane varieties evaluated in two years.

\begin{tabular}{|c|c|c|c|c|c|c|c|c|c|c|c|c|}
\hline \multirow{2}{*}{ Genotypes } & \multicolumn{3}{|c|}{ Stalks height $(\mathrm{cm})$} & \multicolumn{3}{|c|}{ Stalk diameter (cm) } & \multicolumn{3}{|c|}{ Stalk number/m ${ }^{2}$} & \multicolumn{3}{|c|}{ Cane yield (ton/fed) } \\
\hline & Year-1 & Year-2 & Mean & Year-1 & Year-2 & Mean & Year-1 & Year-2 & Mean & Year-1 & Year-2 & Mean \\
\hline G.98-28 & 273.0 & 266.0 & 269.5 & 2.8 & 2.7 & 2.75 & 12.6 & 11.6 & 12.10 & 53.3 & 46.7 & 50.0 \\
\hline G99-165 & 259.7 & 245.3 & 252.5 & 2.6 & 2.7 & 2.65 & 9.0 & 7.7 & 8.35 & 39.8 & 39.3 & 39.5 \\
\hline G95-19 & 285.0 & 253.6 & 269.3 & 3.2 & 3.0 & 3.10 & 11.3 & 9.0 & 10.15 & 51.9 & 48.3 & 50.1 \\
\hline G95-21 & 276.7 & 258.3 & 267.5 & 2.8 & 2.5 & 2.65 & 12.3 & 11.0 & 11.65 & 52.1 & 48.7 & 50.4 \\
\hline G.84-47 & 279.3 & 263.3 & 271.3 & 2.7 & 2.8 & 2.75 & 14.0 & 12.7 & 13.35 & 52.5 & 45.7 & 49.1 \\
\hline & 241.3 & 235.7 & 238.5 & 2.5 & 2.6 & 2.55 & 10.7 & 8.3 & 50 & 45.7 & 39.7 & 42.7 \\
\hline G.T 54-9 & 276.0 & 269.7 & 272.9 & 3.0 & 2.9 & 2.95 & 13.7 & 12.7 & 13.20 & 55.0 & 52.0 & 53.5 \\
\hline El24-3OR 2 & 255.7 & 231.3 & 243.5 & 2.8 & 2.6 & 2.70 & 12.3 & 10.3 & 11.30 & 49.8 & 41.7 & 45.8 \\
\hline $6-9$ & 194.0 & 194.7 & 194.4 & 2.8 & 2.6 & 2.70 & 10.7 & 10.3 & 10.50 & 32.8 & 32.0 & 32.4 \\
\hline $\mathrm{PH} 8013$ & 267.0 & 265.0 & 266.0 & 2.7 & 2.6 & 2.65 & 11.3 & 9.0 & 10.15 & 47.0 & 48.0 & 47.5 \\
\hline MEAN & 260.8 & 248.3 & 254.5 & 2.8 & 2.7 & 2.75 & 11.8 & 10.3 & 11.03 & 48.00 & 44.2 & 46.1 \\
\hline \begin{tabular}{|ll} 
LSD & 0.05 \\
0.01 & \\
\end{tabular} & & $\begin{array}{l}6.580 \\
8.832 \\
\end{array}$ & & & $\begin{array}{l}0.135 \\
0.182\end{array}$ & & & $\begin{array}{l}1.290 \\
1.731\end{array}$ & & & $\begin{array}{l}3.442 \\
4.622\end{array}$ & \\
\hline
\end{tabular}

Table 6. Mean squares from combined analysis of variance for stalk height, diameter and number in addition to cane yield of $\mathbf{1 0}$ sugarcane varieties evaluated in two years.

\begin{tabular}{|l|c|c|c|c|c|}
\hline \multirow{2}{*}{ S.V. } & \multirow{2}{*}{ D.F. } & \multicolumn{5}{|c|}{ Mean Squares (MS) } \\
\cline { 3 - 6 } & & $\begin{array}{c}\text { Stalks } \\
\text { height }\end{array}$ & $\begin{array}{c}\text { Stalk } \\
\text { diameter }\end{array}$ & $\begin{array}{c}\text { Stalk } \\
\text { number/m }\end{array}$ & Cane yield \\
\hline Year & 1 & $2331.267^{*}$ & 0.160 & $35.267^{*}$ & $214.326^{*}$ \\
\hline Rep (Year) & 4 & 302.76 & 0.026 & 3.167 & 18.247 \\
\hline Genotypes & 9 & $3577.84^{* *}$ & $0.182^{* *}$ & $15.363^{* *}$ & $237.745^{\star *}$ \\
\hline G $\times$ Y) & 9 & $157.156^{* *}$ & 0.030 & 0.711 & 14.119 \\
\hline Error & 36 & 47.211 & 0.020 & 1.815 & 12.933 \\
\hline
\end{tabular}

Highly significant differences between the tested varieties were found in all studied traits. Significant differences due to the tested seasons were observed for stalk height, stalk number and cane yield (Table 6). The interaction "genotypes X seasons" was highly significant in stalk height and not significant in other traits. These results implied that there was reasonably sufficient variability in the material used in the present study, which provides ample scope for selecting superior and desired genotypes by the plant breeders for further improvement. These results are in agreement with those obtained earlier by Chaudhary, 2001 and Okaz et al., 2011.

Heritability and genetic advance are very essential to improve any trait of sugarcane because this would help in knowing whether or not the 
desired objective can be achieved from the material (Tyagi and Singh, 1998). The tested traits showed high heritability values ranged from $83.52 \%$ in Stalk diameter to $95.61 \%$ in Stalks height (Table 7). Maximum genetic advance (assuming 20\% intensity of selection) along with high heritability was observed for stalk height ( $\mathrm{GA}=48.09 \%$. $\left.\mathrm{H}^{2}=95.61 \%\right)$, reflecting the preponderance of additive gene action in determining such character (Table 7). This also provides the evidence that larger proportion of phenotypic variance has been attributed to genotypic variance, and reliable selection could be made for this trait on the basis of phenotypic expression. Khan et al. (2007) and Chaudhary (2001) reported great magnitudes of broad sense heritability and high genetic advance in cane yield.

Table (7). Estimates of genetic variance $\left(\delta^{2}\right)$, "genotype $\times$ year" interaction $\left(\delta_{\text {gy }}^{2}\right)$ variance, phenotypic variance $\left(\delta_{p}^{2}\right)$, broad sense heritability $\left(\mathrm{H}^{2}\right)$ and genetic advance $(\mathrm{GA})$ for stalk height, diameter and number in addition to cane yield of 10 sugarcane varieties evaluated in two years, 2011 and 2012.

\begin{tabular}{|l|c|c|c|c|}
\hline $\begin{array}{l}\text { Variances and } \\
\text { genetic } \\
\text { components }\end{array}$ & Stalks height & $\begin{array}{c}\text { Stalk } \\
\text { diameter }\end{array}$ & $\begin{array}{c}\text { Stalk } \\
\text { number/m }\end{array}$ & Cane yield \\
\hline$\delta^{2} q$ & 570.11 & 0.025 & 2.44 & 37.27 \\
\hline$\delta^{2} a y$ & 36.65 & 0.003 & 0.37 & 0.40 \\
\hline$\delta^{2}{ }^{2}$ & 47.21 & 0.020 & 1.82 & 12.93 \\
\hline$\delta_{p}^{2}$ & 596.31 & 0.030 & 2.56 & 39.62 \\
\hline $\mathrm{H}^{2}$ & 95.61 & 83.52 & 95.37 & 94.06 \\
\hline $\mathrm{GA}, 20 \%{ }^{*}$ & 48.09 & 0.20 & 2.14 & 8.29 \\
\hline
\end{tabular}

* GA was calculated at $20 \%$ intensity of selection

The other traits displayed high amount of heritability associated with low genetic advance indicating that non-additive gene action governing these traits, and these characters could be improved through the use of hybridization and hybrid vigor (Table 7). Meanwhile, the most critical point is that high heritability causes for these traits might be due to prevailing of favorable environmental conditions during the seasons rather than genetic cause (Phundan and Naryanan, 1993 and Ahmed and Obeid, 2012).

\section{REFERENCES}

Ahmed A.O. and Obeid, A. 2012. Investigation on variability, broad sensed heritability and genetic advance in Sugarcane (Saccharum spp). Int. J. of Agri. Science 2(9): 839-844.

Alwala ,S.; Suman A, Arro, J.A.; Veremis, J.C.andKimberg, C.A. (2006). Target region amplification polymorphism for assessing genetic diversity in sugarcane germplasm collections. Crop. Sci. 46:448-449.

Andersen, J.R., Lubberstedt ,T.( 2003). Functional markers in plants. Trends Plant Sci 8:554-560. 
Anshuman, S.; Bhatnagar ,P.K.; Khan, A.Q.and Shrotria, P.K. (2002) .Variability and heritability for cane yield, its components and quality characters in sugarcane (Saccharum spp complex). IndSug J 53 4: 717-719.

Arro, J. A. (2005). Genetic diversity among sugarcane clones using the target region amplification polymorphism (TRAP) markers and pedigree relationships. M. Sc. Thesis, Agricultural and Mechanical College, Louisiana State University, USA.145 pages.

Becelaere ,G.V.; Lubbers ,E.L.; Paterson ,A. H. and Chee ,P.W. (2005). Pedigree vs DNA marker-based genetic similarity estimates in cotton. CropSci 45:2281-2287.

Chaudhary, R.R. 2001.Genetic variability and heritability in sugarcane. Nepal Agric. Res. J. Vol. 4 \& 5: 56-59.

Creste, S.; Accoroni, K.A.G.; Pinto, L.R.; Vencovsky, R.; Gimenes, M.A; Xavier, M.A. and Landell, M.G.A. (2010). Genetic variability among sugarcane genotypes based on polymorphisms in sucrose metabolism and drought tolerance genes. Euphytica 172:435-446

Dellaporta, S.L., Wood, J. and Hicks, J.B. (1983). A plant DNA minipreparation.Version II. Plant Molecular Biology Reporter 1: 19-21.

D'Hont, A.; Grivet,L.; Feldmann, P.; Rao,S.; Berding,N. and Glaszmann., J. C. (1996). Characterisation of the double genome structure of modern sugarcane cultivars (Saccharum spp.) by molecular cytogenetics. Mol.Gen.Genet. 250: 405-413

Fawaz, W.A. (2014). Molecular Biological Studies on Sugarcane. Ph.D. Thesis, Sadat City University, Institute of Genetic Engineering and Biotechnology.

Fehr, W.R. (1987.). Principles of Cultivar Development.Vol.1 MacMillan Publishing Co. New York.

Houde M, Belcaid M, Ouellet F, et al. (2006). Wheat EST resources for functional genomics of abiotic stress. BMC Genomics.7:149.

Hu, J.G., and Vick.B.A. (2003) Target region amplification polymorphism: A novel marker technique for plant genotyping. Plant Mol. Biol. Rep. 21:289-294.

Kang, M.S., Miller, J.D. and Tai, P.Y.P. (1983). Genetic and phenotypic path analyses and heritability in sugarcane. Crop Sci., 23: 643-647.

Khan, I.A.; Umar Dahot, M. and A. Khatri. 2007. Study of genetic variability in sugarcane induced through mutation breeding. Pak. J. Bot., 39(5): 1489-1501, 2007.

Khan, I.A.; Bibi, S.; Yasmeen, S.; Seema, N.; Khatri. A; Siddiqui, m. A.; Nizamani, G.S and Afghan, S. (2011). Identification of elite sugarcane clones through TRAP. Pak. J. Bot., 43(1): 261-269.

$\mathrm{Li}, \mathrm{G}$ and Quiros.C.F. (2001). Sequence related amplified polymorphism (SRAP), a new marker system based on a simple PCR reaction: its application to mapping and gene tagging in Brassica. Theor. Appl. Genet. 103: 455-461. 
Li, A.; Xiang Wang, Charles H. Leseberg, JizengJia and Long Mao. 2008. Biotic and abiotic stress responses through calcium-dependent protein kinase (CDPK) signaling in wheat (Triticuma estivum L.). Plant Signaling \& Behavior 3:9, 654-656

Lian, H.L.; Yu, X.; Ye, Q.; Ding, X.; Kitagawa, Y.; Kwak,S.S.;Su ,W.A. and Tang, Z.C. (2004). The role of aquaporin RWC3 in drought avoidance in rice. Pant Cell Physiol. 45:481-489.

Ming, R., S.C. Liu, P.H. Moore, J.E. Irvine, and A.H. Paterson. (2001). QTL analysis in a complex autopolyploid: Genetic control of sugar content in sugarcane. Genome Res 11:2075-2084.

Morillon, R. and Lassalles, J. P.(2002). Water deficit during root development: effects on the growth of roots and osmotic water permeability of isolated root protoplasts. Planta. 214(3):392-399.

Nei, M. and Li., W.H. (1979). Mathematical Model for studying genetic variation in terms of restriction endonucleases. Proc. Natl. Acad. Sci., USA 96: 5269-5273.

Okaz, A.M.; Mohamed, B.D.; Abd-El-Haleem, S.H.M. and E.M.M. Yousif (2011). Stability parameters of cane yield and its components under various planting dates and interrow spacing for ten sugarcane genotypes (Saccharum spp.). American-Eurasian J. Agric. \& Environ. Sci. 11(6): 929-937.

Phundan, S. and S.S. Naryanan. 1993. Biometrical Technique in Plant breeding. Khalyani Publisher $1^{\text {st }}$ (ed). New Delhi 110 002.74-84.

Skinner, J.C., D.M. Hogarth, and K.K. Wu. 1987. Selection methods, criteria and indices. In: Heinz D.J. (ed.) Sugarcane improvement through breeding. Elsevier, Amsterdam. p. 409-453.

Tyagi, S.D. and D.N. Singh. 1998. Studies on genetic variability for stalk characters in sugarcane. Indian Sugar XL VIII:259-262.

Vettore, A. L.; Silva, F. R.; Kemper, E. L. Arruda, P. (2001).The libraries that made. SUCEST.Genet. Mol. Bio I24:1-7. 


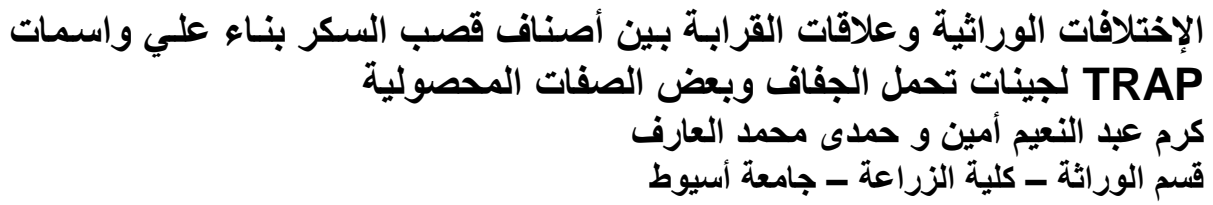

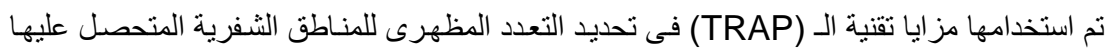

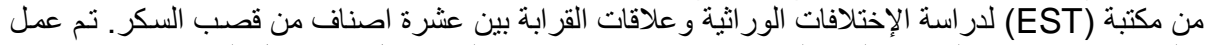

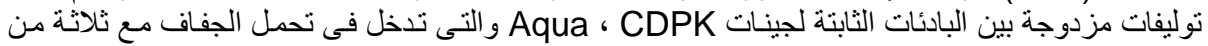

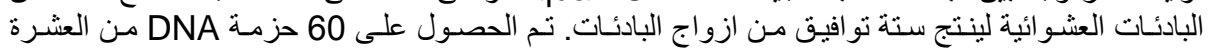

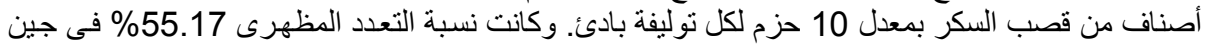

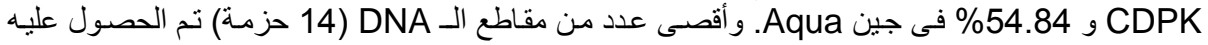

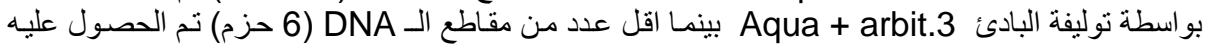

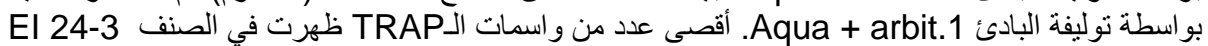

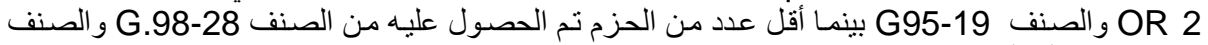

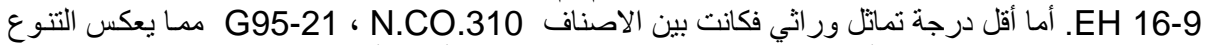

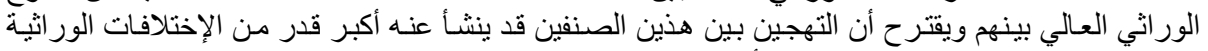

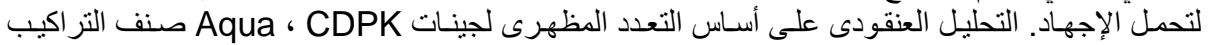

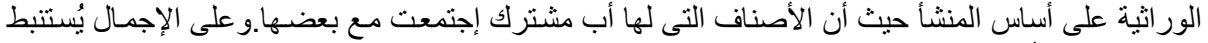

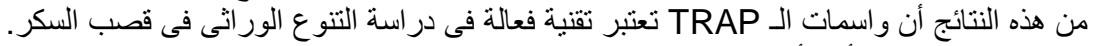

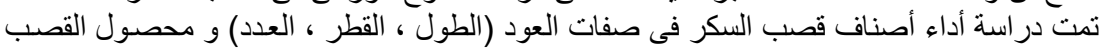

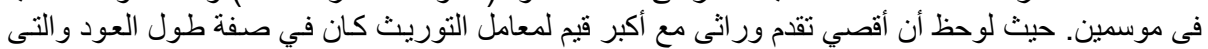

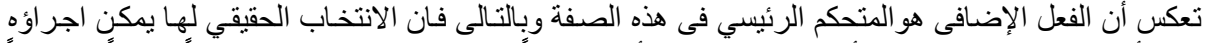

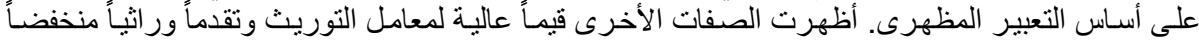

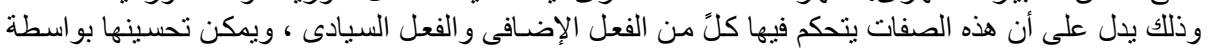

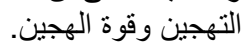

